\title{
Fracture and Fatigue Analysis for a Cracked Carabiner Using 3D Finite Element Simulations
}

\author{
M. R. M. Aliha, ${ }^{a, 1}$ A. Bahmani, ${ }^{a, b}$ and S. Akhondi ${ }^{\text {b }}$ \\ ${ }^{a}$ Welding and Joining Research Center, School of Industrial Engineering, Iran University of Science \\ and Technology (IUST), Narmak, Tehran, Iran \\ ${ }^{\mathrm{b}}$ Department of Sport Engineering, Science and Research Branch, Islamic Azad University, Tehran, \\ Iran \\ ${ }^{1}$ mrm_aliha@iust.ac.ir
}

УДК 539.4

\section{Анализ усталостного разрушения соединительного карабина с трещиной методом трехмерных конечных элементов}

\author{
М. Р. М. Алиха ${ }^{a}$ А. Бахмани ${ }^{a, \sigma}$, С. Ахонди \\ a Иранский университет науки и технологии, Нармак, Тегеран, Иран \\ ${ }^{\sigma}$ Исламский университет Азад, Тегеран, Иран
}

Выполнено численное моделирование процесса усталостного разрушения соединительного карабина из сплава Al-7075 с малой краевой трещиной для типичных условий эксплуатационного нагружения. С использованием метода конечных элементов в трехмерной постановке определены характеристики разрушения материала по смешанной моде для различных условий нагружения и конфигуращий трещины (включая ее длину, глубину и угол наклона). Согласно полученным результатам, деформацией исследуемого карабина по моде III ввиду ее малости можно пренебречь, вследствие чего разрушение происходит по смешанному механизму отрывасдвига (смешанная мода I/II). Проведен расчет коэффициентов интенсивности напряжений $\left(K_{I} \quad\right.$ и $\left.K_{I I}\right)$ и сингулярных Т-напряжений. Показано, что знак и значение этих параметров разрушения определяются геометрией и ориентацией трещины. Рассчитаны критическая длина трещины и живучесть карабина с трещиной при повторно-переменном нагружении на основании известных критериев разрушения и моделей роста усталостной трещинь.

Ключевые слова: соединительный карабин, параметры разрушения, трехмерный конечноэлементный расчет, смешанная мода разрушения, усталостная долговечность.

\section{Notation}

A $\quad-$ crack width

$L \quad-$ a constant and characteristic length in the carabiner

$r, \theta-$ crack tip coordinate

$C, m, B^{*}, m^{*}-$ coefficients of fatigue crack growth

$B \quad-$ biaxiality ratio

$E \quad-$ elastic modulus

$K_{\text {I }}, K_{\text {II }}, K_{\text {III }}$ - mode I, mode II, and mode III stress intensity factors

$K_{\text {Ic }} \quad-$ mode I fracture toughness 


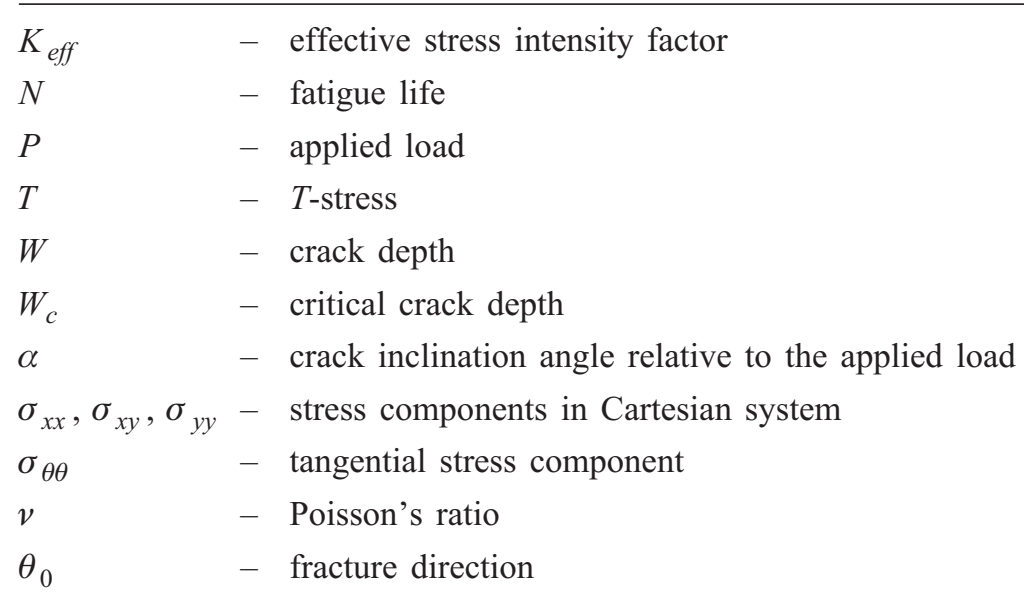

Introduction. A carabiner is a metal or composite loop having a spring gate or screw locking gate, which is frequently used by mountain- or rock-climbers to protect them from sudden falling. One end of the carabiner is clipped around a rope that is attached to the climber and the other end is clipped around a piece of webbing that is attached to the mountainside or rocks. This equipment is also employed in other activities such as industrial (window cleaning, construction work, fire service departments and rope rescue operations), sports (sailing, climbing, hang gliding, canyoning, caving and slack lining), camping equipments, marine equipments etc. Figure 1 shows a typical type of carabiner and different applications of carabiners. Since these equipments are employed in dangerous activities, their design and safe service conditions are of great importance. Hence the strength, load bearing capacity and their failure resistance against sudden fracturing and fatigue crack growth are key issues that should be known for the safe and reliable using of carabiners. In the past decades some international groups and researchers have studied the mechanical and strength properties of carabiners from different aspects. For example, the ASTM has proposed a standard method for testing the strength of carabiners using a tensile test procedure [1]. Accordingly, carabiners are designed to repeatedly withstand the loads of climbing falls, which are typically between 2 and $20 \mathrm{kN}$, but in extreme cases they can be as high as $20 \mathrm{kN}$. Walk [2] experimentally examined the high cycle fatigue behavior of carabiners and showed that after almost 500,000 loading cycles with amplitude of $2 \mathrm{kN}$, a plastic deformation of $1 \mathrm{~mm}$ is induced in the tested carabiner. Custer and Dave [3] experimentally proved that the mentioned range for load bearing capacity of carabiners subjected to moderately high amplitudes of cyclic loads does not provide conservative estimations for typical types of available carabiners. Blair et al. [4] studied the deformation and crack growth behavior of D type aluminum carabiners under cyclic loading. Scott [5] investigated the use of composite materials for manufacturing carabiners to improve strength, weight and impact properties of carabiners. They showed that a composite carabiner made of short carbon fibers can improve noticeably the strength and mechanical properties. Meanwhile the weight of composite carabiner was also up to $40 \%$ less than the similar aluminum type carabiners.

However, catastrophic failure due to the crack growth and fracture is one of the possible damage modes for carabiners. Cracks or sharp notches can be initiated inside or in the inner surfaces of the carabiner during its service life (for example due to extra and sudden loads, cyclic fatigue loads, impact or contact between carabiner and webbing metal, etc.) and especially at cold climates and under low temperatures. These cracks may then grow due to repeated loading-unloading cycles induced by the weight of climbers. Hence it is necessary to study the effect of such cracks in the reliability and load bearing capacity of 

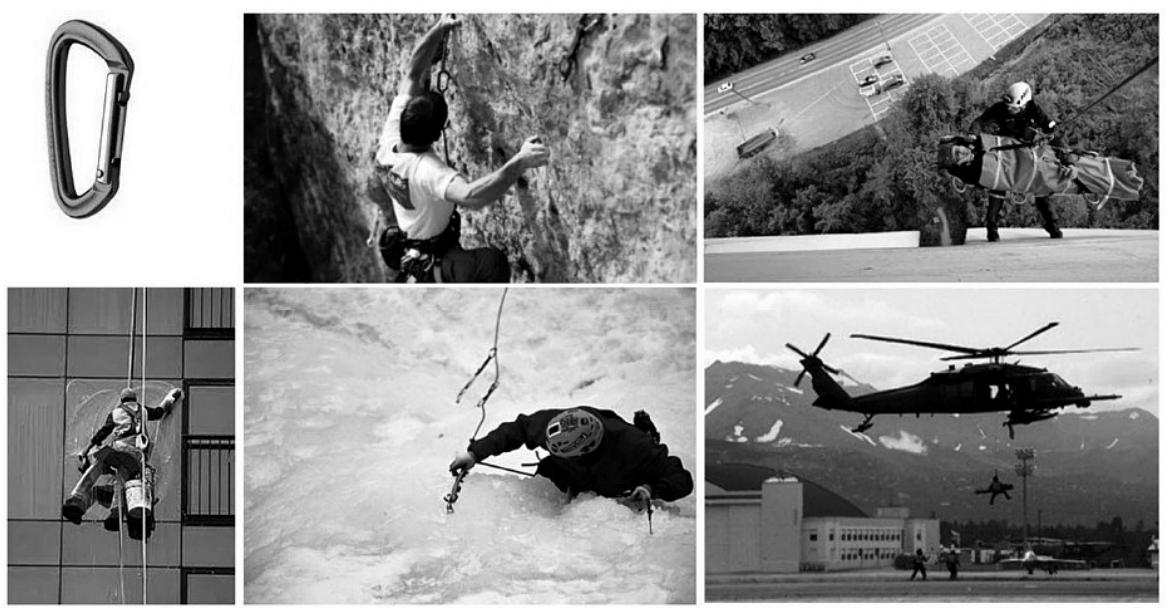

Fig. 1. Carabiner and its different applications.

carabiners. However, crack growth analysis of such equipments have been rarely investigated in the past and therefore, in this paper the crack growth behavior of a carabiner containing a very small crack initiated in the inner surface of carabiner is investigated numerically using the finite element method. first the fracture parameters of a typical cracked carabiner are computed from the finite element simulations for various loading conditions and crack dimensions. The critical crack depth and the fatigue life of the investigated carabiner are then computed numerically for the investigated carabiner.

Fracture Parameters for a Cracked Component. Crack faces in any desired component subjected to an arbitrary loading can experience three basic modes of deformations, namely mode I (crack opening or tensile), mode II (in-plane sliding or shear) and mode III (out of plane sliding or tear) deformations. Fracture mechanics is a suitable discipline for dealing with the problems containing cracked components subjected to mechanical, thermal or environmental loads. In this framework, the state of stresses at the vicinity of crack front is considered for evaluating the fracture behavior and load bearing capacity of the cracked components. Due to the complexity of geometry and applied loads, real cracked components often experience different combinations of three basic fracture modes and in vast majority of practical cases, the fracture of most structures occurs usually under mixed mode I/II (combined tensile-shear) loading conditions. The crack tip stress field in a cracked component subjected to mixed mode I/II can be written as an infinite series expansion outlined by Williams [6] as follows:

$$
\begin{gathered}
\left\{\begin{array}{l}
\sigma_{x x} \\
\sigma_{y y} \\
\sigma_{\xi \psi}
\end{array}\right\}=\frac{1}{\sqrt{2 \pi r}}\left[\begin{array}{rr}
\left(\cos \frac{\theta}{2}-\frac{1}{2} \sin \theta \sin \frac{3 \theta}{2}\right) & \left(-2 \sin \frac{\theta}{2}+\frac{1}{2} \sin \theta \cos \frac{3 \theta}{2}\right) \\
\left(\cos \frac{\theta}{2}+\frac{1}{2} \sin \theta \sin \frac{3 \theta}{2}\right) & \left(\frac{1}{2} \sin \theta \cos \frac{3 \theta}{2}\right) \\
\left(\frac{1}{2} \sin \theta \cos \frac{3 \theta}{2}\right) & \left(\cos \frac{\theta}{2}-\frac{1}{2} \sin \theta \sin \frac{3 \theta}{2}\right)
\end{array}\right]\left\{\begin{array}{l}
K_{\mathrm{I}} \\
K_{\mathrm{II}}
\end{array}\right\}+ \\
+\left[\begin{array}{c}
T \\
0 \\
0
\end{array}\right]+\left\{\begin{array}{l}
O\left(r^{1 / 2}\right) \\
O\left(r^{1 / 2}\right) \\
O\left(r^{1 / 2}\right)
\end{array}\right\}
\end{gathered}
$$




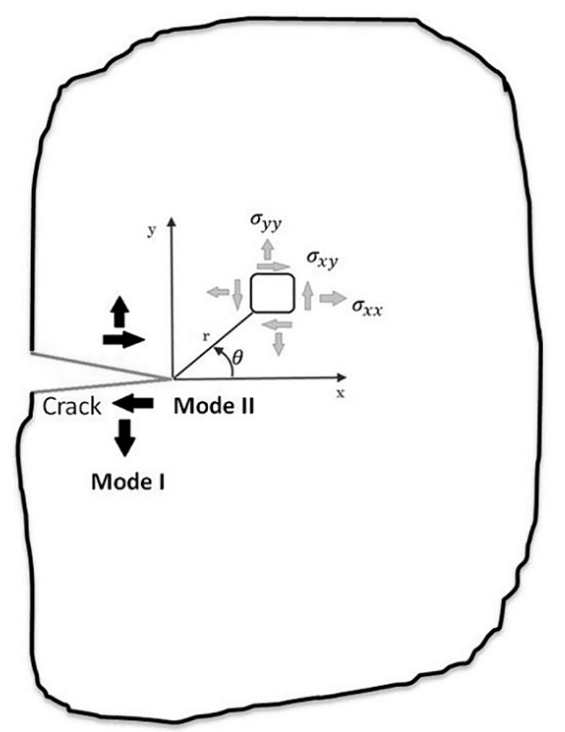

Fig. 2. Crack tip stress component under mixed mode I/II loading.

where $\sigma_{x x}, \sigma_{x y}$, and $\sigma_{y y}$ are the stress components in a Cartesian system, $r$ and $\theta$ are the crack tip polar coordinates with origin located at the tip of crack (see Fig. 2). As seen from Eq. (1), the first term is singular and the second term is a constant nonsingular term independent of distance from the crack tip. It is now widely accepted that the mode I and mode II stress intensity factors $\left(K_{\mathrm{I}}\right.$ and $\left.K_{\mathrm{II}}\right)$ which are related to the singular terms and the constant non singular stress term (called the $T$-stress) are three fundamental fracture parameters for describing the crack tip stresses in a cracked component subjected to mixed mode I/II (i.e., combined tension-shear) loading [7-13]. While the stress intensity factors describe the severity of stress singularity around the crack tip, the $T$-stress can influence significantly the initiation of fracture and the trajectory of fracture growth. Other terms represented by $O\left(r^{1 / 2}\right)$ in Eq. (1) are usually negligible in the vicinity of the crack tip. Accordingly, in order to study the fracture behavior of cracked components subjected to mixed mode loading, it is necessary that the three fracture parameters $\left(K_{\mathrm{I}}, K_{\mathrm{II}}\right.$, and $T$-stress) are known for the given applied loading condition. Hence in the upcoming sections of this paper, the fracture parameters of a carabiner containing a crack and subjected to a typical loading (which it often experiences at service conditions) is obtained numerically for different crack geometries and crack dimensions. By modeling and analyzing a three dimensional carabiner in the ABAQUS finite element software, variations of $K_{\mathrm{I}}, K_{\mathrm{II}}$, and $T$ are computed for different crack geometries and mixed mode conditions.

3D Modeling of a Carabiner. A three dimensional model of a typical D type carabiner (manufactured by PETZL company in France) with real geometry and dimensions were created by laser scanning of the carabiner. Then the data points obtained from the laser scanning, were imported into a GEOMAGIC software to create a real three dimensional (3D) solid model of carabiner (see Fig. 3 for the created model). The use of finite element technique is a power full and sometimes the only available method for stress analysis of such complex 3D structures. The use of this technique has been widely increased in recent years for analyzing and simulating the mechanical behavior of many types of sport devices and equipments (such as sport balls containing rigid foams, golf ball and club, racing car chassis, tennis ball, baseball bat and footwear) [14-18]. Hence, in order to analyze a carabiner, the created 3D solid model was imported into the ABAQUS finite element 


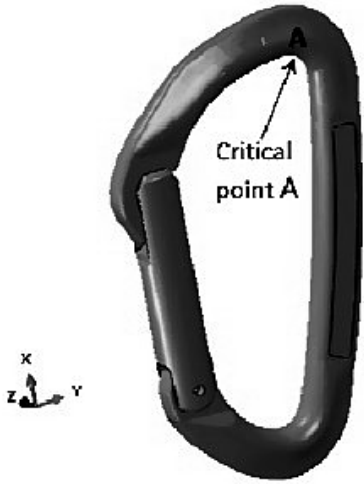

a

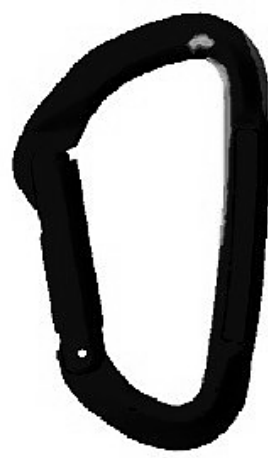

b

Fig. 3. 3D model of a D type carbineer created by laser scanning technique (a) and the location of critical point obtained from stress analysis of carabiner for introducing a crack (b).

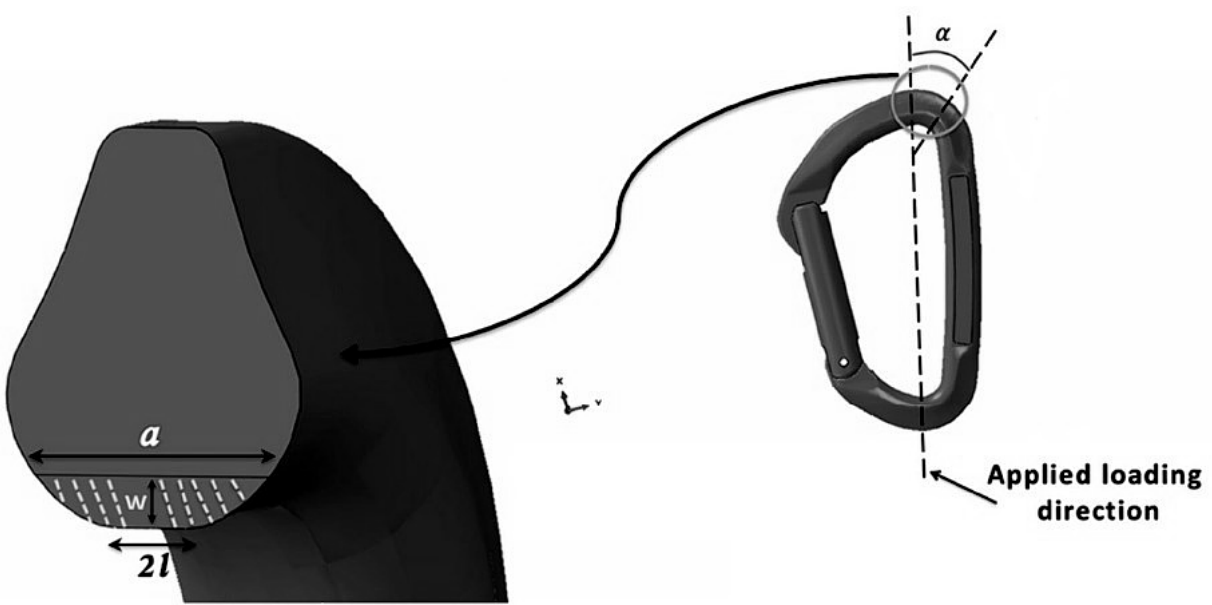

Fig. 4. Geometry, location and orientation of 3D surface crack initiated at the inner surface of carabiner.

software and a finite element model of carabiner was created using a total number of 153,274 tetragonal and hexagonal solid elements. Also, the critical region $A$ (shown in Fig. 3) was chosen for considering a crack at the inner surface of the investigated carabiner. Finite element stress analysis of the un-cracked carabiner under a typical service loading, showed that this location experiences high stress concentrations and due to the type of applied loads in this area which are a combinations of wear, cyclic loading-unloading forces, contact and dynamic shocks, the location $A$ is more vulnerable area for nucleation of cracks. Hence a small 3D straight thorough thickness edge crack with width $a$ and depth $W$ was also modeled in this region. Figure 4 shows the geometry of crack initiated at the inner surface of carabiner with a typical direction of load applied to the carabiners in real situations. Crack plane can make an angle $(\alpha)$ relative to this loading direction which is also shown in Fig. 4. In order to produce a square root singularity of the stress field, singular (quarter point) elements are used in the first ring of finite elements surrounding the 3D crack front. Figure 5 shows the mesh pattern generated for the modeled carabiner.

The load and boundary conditions that is applied in practice to the carabiners was also considered in the finite element model. Accordingly, a reference load of $1200 \mathrm{~N}$ (i.e., typical weight of a person with his/her equipments) was applied to the top inner surface of 


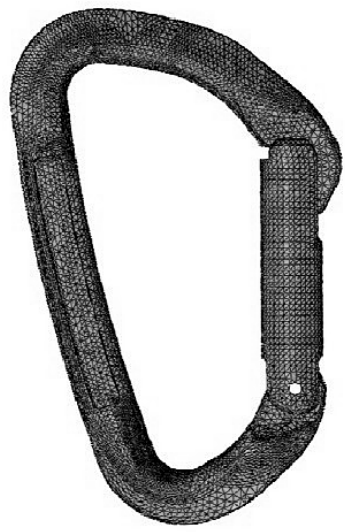

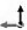

Fig. 5. Mesh pattern created for finite element modeling of carabiner.

the carabiner and the opposite bottom inner surface along the line of loading was fixed. Material properties of a 7075 aluminum alloy used for manufacturing the most of metal carabiners were also used in the models as $E=71 \mathrm{GPa}$ and $v=0.33$. For the modeled carabiner the fracture parameters are functions of the crack geometry (i.e., the width $a$ and depth $W$ ), applied load $(P)$ and the crack angle $(\alpha)$, and can be written as

$$
\begin{gathered}
K_{\mathrm{I}}=f(W / l, a / l, \alpha, P), \\
K_{\mathrm{II}}=f(W / l, a / l, \alpha, P), \\
T=f(W / l, a / l, \alpha, P),
\end{gathered}
$$

where $l$ is a constant length in the modeled carabiner which has been defined in Fig. 4. By performing several 3D finite element analyses, the fracture parameters were obtained directly from $J$-integral method built in ABAQUS code [19] for different geometry and loading conditions of the cracked carabiner. In this method by performing a static analysis under monotonic loading for the cracked component, the strain energy release rate per unite fracture surface in front of the crack tip is obtained using a path independent contour integral (called $J$-integral). Using the value of this energy, $K_{\mathrm{I}}, K_{\mathrm{II}}$, and $T$ can be determined from the available relations [19]. Figure 6 shows the contours of von Mises stress for the whole analyzed carabiner and a zoomed view of von Mises crack tip stresses that revels the severity of stresses in this region as a critical location of the total model. In the next section, the obtained results are presented and discussed.

Results and Discussion. The variations of mode I and mode II stress intensity factors $\left(K_{\mathrm{I}}\right.$ and $\left.K_{\mathrm{II}}\right)$ for different crack inclination angles and crack width and depth ratios $(\mathrm{W} / \mathrm{l}$ and $a / l)$ have been presented in Figs. 7 and 8 . The finite element results showed that the mode III stress intensity factor $\left(K_{\mathrm{III}}\right)$ was nearly zero and negligible in the whole analyzed models and in general a combined mixed mode I/II (tension-shear) fracture mechanism would control the failure of the investigated cracked carabiner in this research. As seen from Fig. 7, $K_{\mathrm{I}}$ increases by increasing the depth and width of crack, but it becomes smaller for greater crack inclination angles $(\alpha)$. However, according to Fig. 8, the variations of mode II stress intensity factor with crack geometry is ascending for small cracks and descending for cracks with greater depth. Figure 9 also compares the $K_{\mathrm{I}} / K_{\mathrm{II}}$ ratio that 


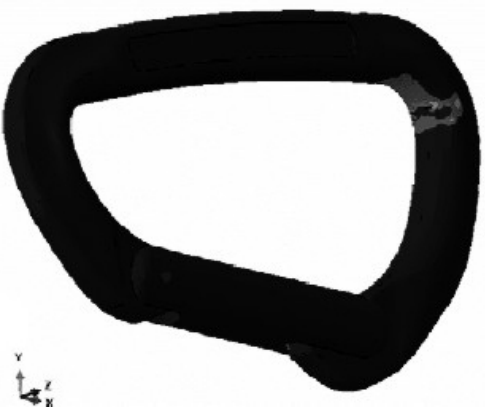

a

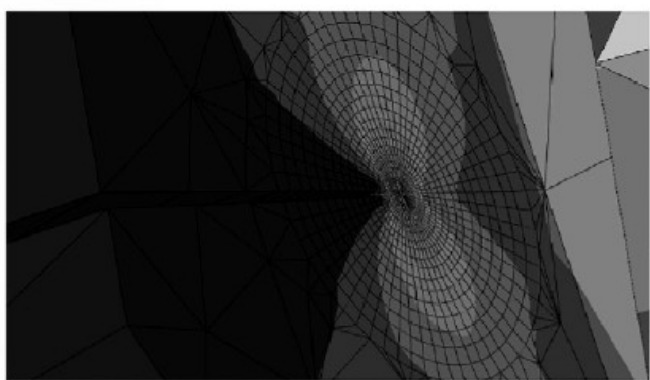

b

Fig. 6. Contours of von Mises stress in the analyzed cracked carabiner (a) and a zoomed view of the crack tip stresses (b).
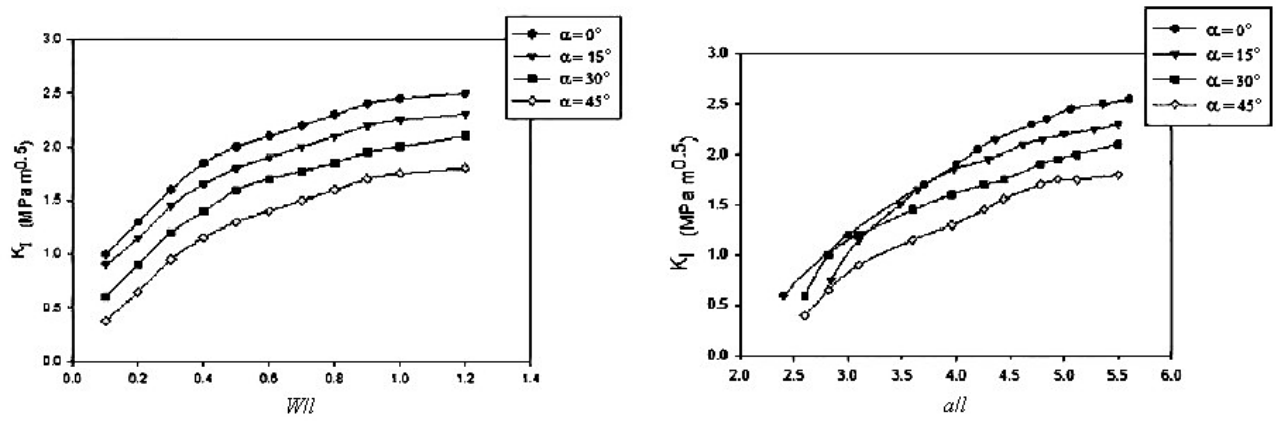

Fig. 7. Variation of mode I stress intensity factor $K_{\mathrm{I}}$ with $W / l$ and $a / l$ for different crack inclination angles $\alpha$.
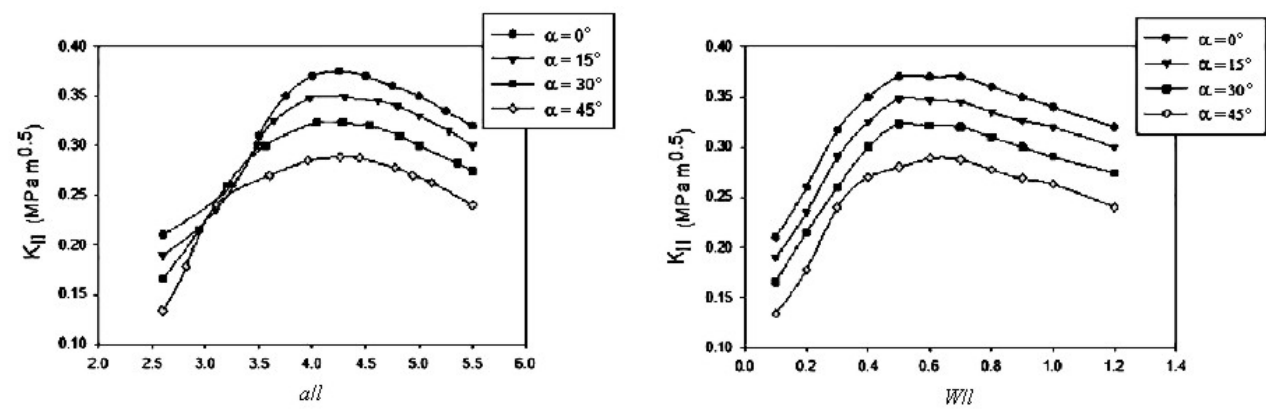

Fig. 8. Variation of mode II stress intensity factor $K_{\mathrm{II}}$ with $a / l$ and $W / l$ for different crack inclination angles $\alpha$.

reveals the mode I component is very much noticeable than the mode II in the analyzed carabiner especially for the larger cracks. For mixed mode loading conditions an effective stress intensity factor is usually used for estimating the equivalent value of fracture toughness. A review of literature shows that several theoretical and empirical based models have been proposed for calculation of effective mixed mode stress intensity factor. For example, Richard [20] proposed an empirical estimation for calculation of the effective mixed mode I/II stress intensity factor. Based on the maximum tangential stress and the maximum energy release rate criteria, Yan et al. [21], Rhee and Salama [22], and Forth et 

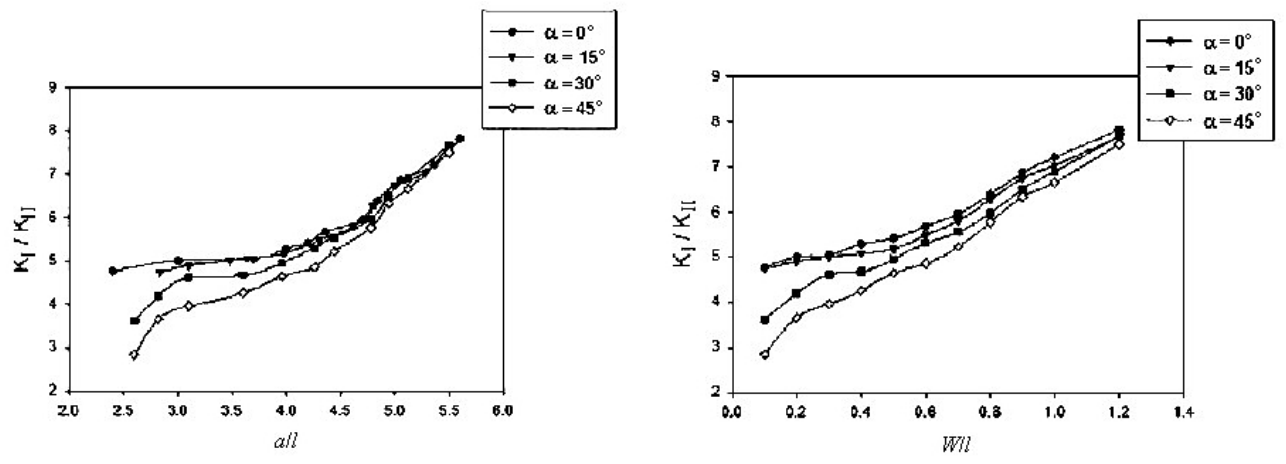

Fig. 9. Variation of $K_{\mathrm{I}} / K_{\mathrm{II}}$ ratio in the analyzed carabineer with $a / l$ and $W / l$ for different crack inclination angles $\alpha$.
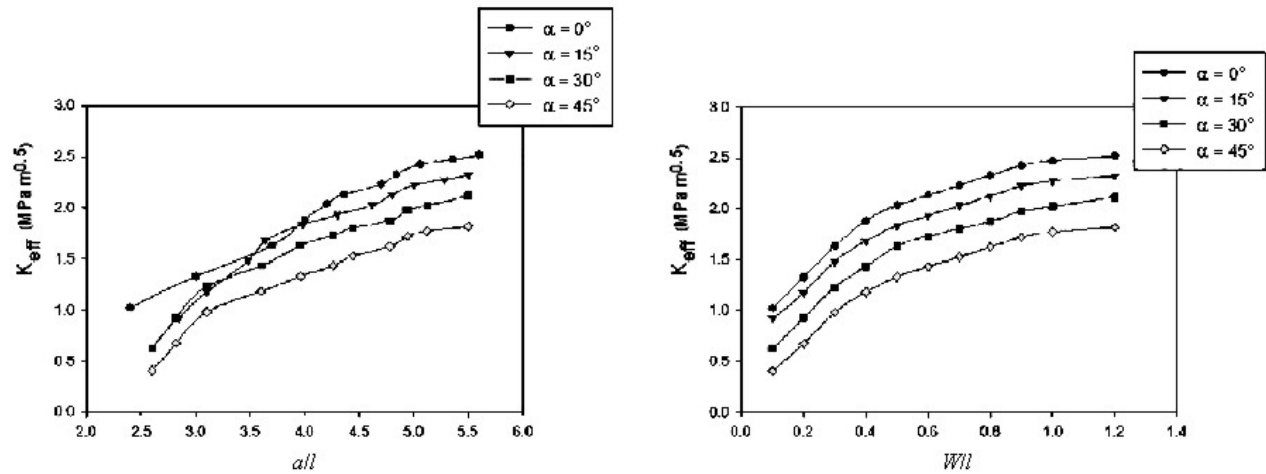

Fig. 10. Variation of effective stress intensity factor $K_{\text {eff }}$ with $a / l$ and $W / l$ for different crack inclination angles $\alpha$.
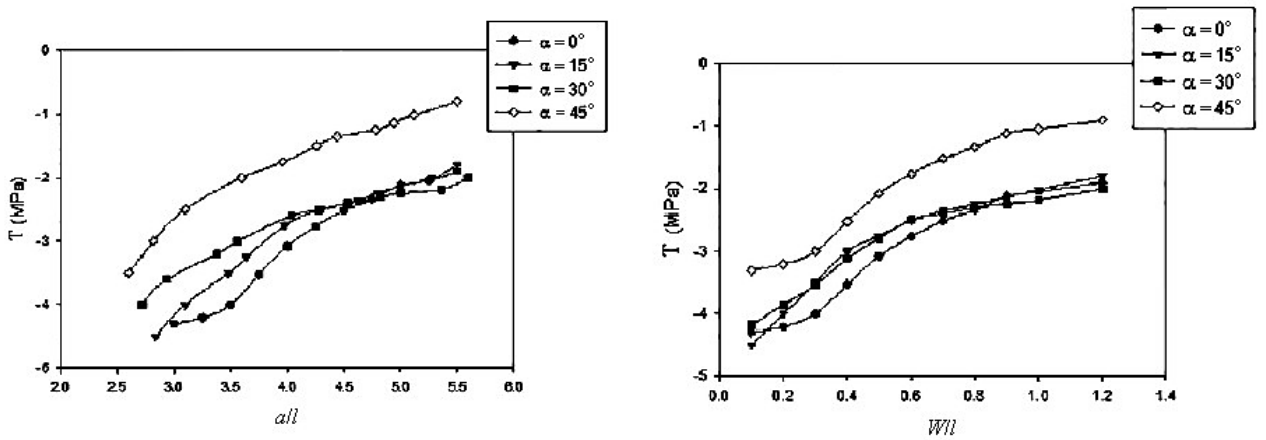

Fig. 11. Variation of $T$-stress with $a / l$ and $W / l$ for different crack inclination angles $\alpha$.

al. [23] proposed different equations for estimating the effective mixed mode I/II and mixed mode I/II/III stress intensity factors. Tanaka [24] and Liu and Mahadevan [25] proposed also some models for obtaining the effective stress intensity factors based on the fatigue crack growth assumptions. Among the mentioned models, the effective mixed mode I/II fracture toughness $K_{\text {eff }}$ derived based on the maximum energy release rate criterion and defined as $[22,23]$ :

$$
K_{e f f}=\sqrt{K_{\mathrm{I}}^{2}+K_{\mathrm{II}}^{2}}
$$


is the simplest and the most convenient one which is a measure of cracked material against mixed mode I/II fracture; since the length of chord passing from the origin of $K_{\mathrm{I}}$ versus $K_{\text {II }}$ failure envelopes shows the magnitude of mixed mode fracture toughness.

Figure 10 shows the variations of $K_{\text {eff }}$ in the analyzed carabiner for different geometry and loading conditions. As seen from this figure, the value of effective fracture toughness increases for greater cracks and smaller crack inclination angles.

Figure 11 presents the variations of $T$-stress in the analyzed cracked carabiner. As is seen from this figure, the $T$-stress generally increases when the depth and length of crack becomes higher. According to the previous research studies, mixed mode I/II fracture toughness depends on the sign and magnitude of $T$-stress [26-30]. Hence, the negative $T$-stresses that exist in the whole models of the analyzed carabiner can increase its load bearing capacity [26-28]. Also these negative $T$-stresses decrease the angle of fracture initiation and hence can influence the path of fracture trajectory [9, 26-28, 31]. Moreover, as seen from Fig. 11, the influence of $T$-stress is more pronounced for smaller cracks and lower crack inclination angles.

For investigating the influence of non singular stress term ( $T$-stress) relative to the singular terms (i.e., $K_{\mathrm{I}}$ and $K_{\mathrm{II}}$ ) a nondimensional parameter called the biaxiality ratio $(B)$ is commonly used [32]. Value of $B$ is defined as

$$
B=\frac{T \sqrt{\pi W}}{K_{e f f}} .
$$

Hence, a greater value of $B$ reveals that the $T$-stress has significant role in the process of mixed mode fracture. The values of $B$ for the investigated carabiner and for different geometry and loading conditions have been determined from Eq. (6) and presented in Fig. 12. In comparison with other cracked components and specimens [26-29], the obtained $B$ data for the analyzed carabiner are very noticeable, which shows the significant influence of non singular stress term ( $T$-stress) on fracture behavior of the analyzed cracked carabiner and especially for small cracks.
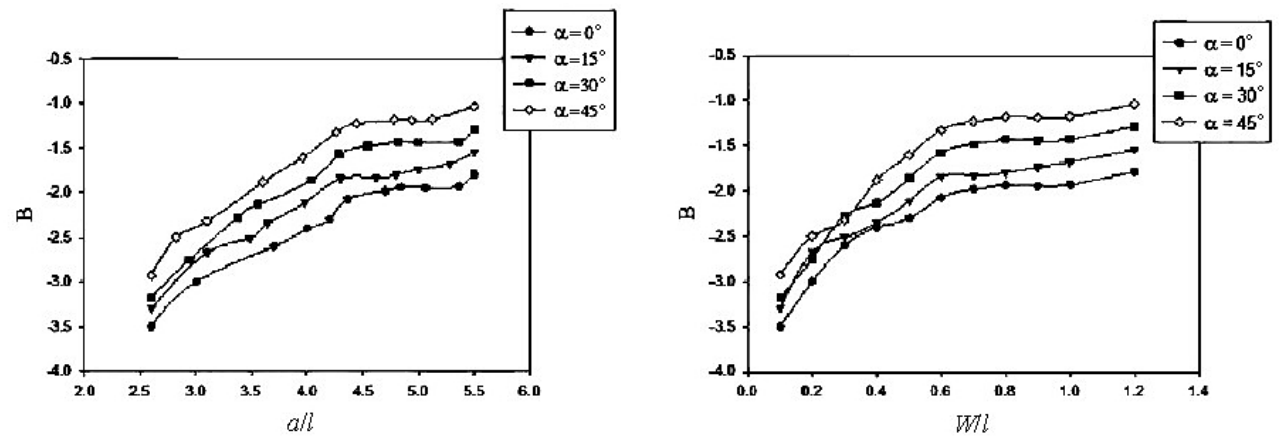

Fig. 12. Variation of biaxiality ratio $B$ with $a / l$ and $W / l$ for different crack inclination angles $\alpha$.

Under mixed mode loading, crack growth direction is not along the plane of initial crack and fracture may initiate along the noncoplanar direction (i.e., along a curvilinear path). Different criteria have been proposed to estimate the direction of mixed mode I/II fracture initiation, e.g., [33-36]. For example, the maximum tangential stress criterion states that mixed mode fracture occurs along the direction where the tangential stress in front of the crack tip is maximum. The tangential stress component can be written as 


$$
\sigma_{\theta \theta}=\frac{1}{\sqrt{2 \pi r}} \cos \frac{\theta}{2}\left[K_{\mathrm{I}} \cos ^{2} \frac{\theta}{2}-1.5 K_{\mathrm{II}} \sin \theta\right]+T \sin ^{2} \theta+O\left(r^{1 / 2}\right) .
$$

Hence the crack initiation direction can be obtained from

$$
\left.\frac{\partial \sigma_{\theta \theta}}{\partial \theta}\right|_{\theta=\theta_{0}}=0,\left.\quad \frac{\partial^{2} \sigma_{\theta \theta}}{\partial \theta^{2}}\right|_{\theta=\theta_{0}}<0 .
$$

By using the fracture parameters computed for the investigated carabiner, the value of $\theta_{0}$ were determined from Eq. (8) for different loading and geometrical conditions. Figure 13 shows the variations of $\theta_{0}$ with $a / l, W / l$, and $\alpha$ in the analyzed carabiner.
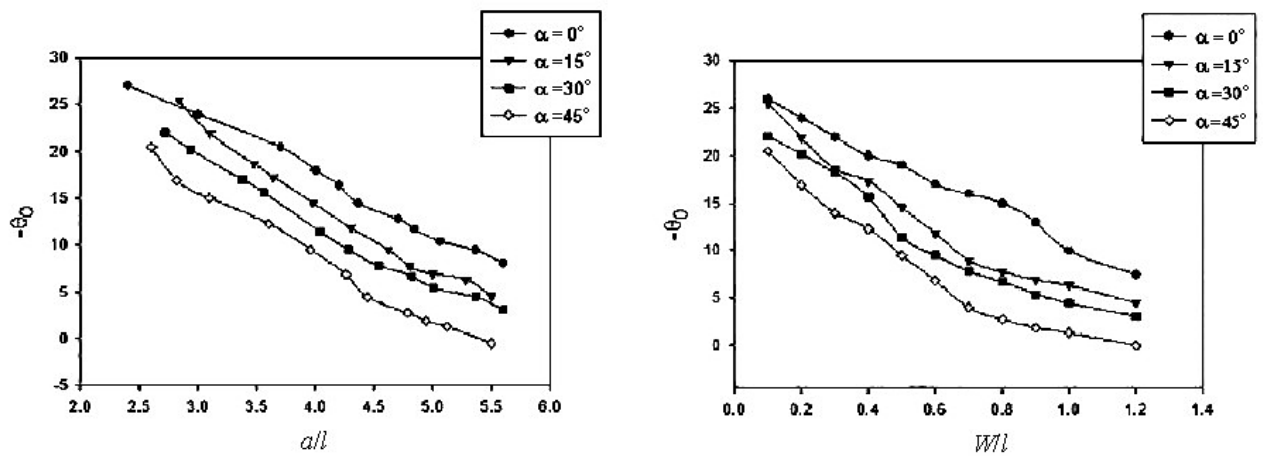

Fig. 13. Variation of fracture initiation angle $\theta_{0}$ with $a / l$ and $W / l$ for different crack inclination angles $\alpha$.

Finite element analysis of the investigated carabiner containing a small edge crack showed that the influence of both stress intensity factors $\left(K_{\mathrm{I}}\right.$ and $\left.K_{\mathrm{II}}\right)$ and the $T$-stress on the onset of fracture and load bearing capacity of the cracked carabiner can be noticeable. Therefore, in order to increase the reliability of such devices and avoid catastrophic failures due to crack growth from probably initiated notches or cracks in these equipments, it is necessary that fracture mechanics based design of such devises to be considered in addition to the conventional design disciplines. At a critical level of applied load or at a critical crack length or depth, the value of fracture parameters reach their critical values such that the required conditions for failure of body is satisfied. The fracture parameters obtained in this research can be help full for estimating the onset of crack growth in the analyzed carabiner using the available mixed mode fracture criteria. Accordingly, when the parameters such as stress, strain or energy at the tip of crack, exceed the critical fracture toughness $\left(K_{\mathrm{I} c}\right)$ of the cracked material (which is a constant material property), fracture of component would be expected to occur under mixed mode tension-shear conditions.

However, based on the numerical results of this research, the magnitudes of static loads applied due to the weight of a person with a climbing equipment (typically about $120 \mathrm{~kg}$ or $1200 \mathrm{~N}$ ) are much less than the required value of critical stress intensity factor for propagating the fracture from the very small cracks considered in the investigated carabiner. While, for the given load and crack geometries the magnitudes of computed stress intensity factors for the analyzed carabiner were typically less than $2 \mathrm{MPa} \cdot \mathrm{m}^{0.5}$, the critical fracture toughness of Al-7075 material varies in the range of 20 and $30 \mathrm{MPa} \cdot \mathrm{m}^{0.5}$ [37]. This means that the probability of crack growth from such very small cracks in the 
carabiners subjected to general tensile service loads (for example the weight of climbers) is very low. However, for larger crack depths (which can be occurred due to the gradually fatigue crack growth in the carabiner subjected to repeated loading-unloading static loads) the risk of crack propagation becomes more in the investigated carabiner. The critical crack depth $\left(W_{c}\right)$ for each crack orientation angle analyzed in this paper was thus determined using several extra finite element analyses. In order to estimate $W_{c}$, crack depth was increased in the finite element models by increment of $1 \mathrm{~mm}$ in each step and the corresponding values of $K_{\mathrm{I}}$ and $K_{\mathrm{II}}$ were computed from the finite element analyses. The obtained stress intensity factors were then compared with the fracture toughness of Al-7075 material (i.e., equal with $24 \mathrm{MPa} \cdot \mathrm{m}^{0.5}$ [37]) by employing the available mixed mode fracture criteria to predict whether the fracture has occurred or not? For example, according to the maximum tangential stress criterion, fracture of a body subjected to mixed mode loading condition takes place when the contribution of mode I and mode II stress intensity factors presented in the right hand side of Eq. (9) reaches or exceeds the critical fracture toughness $\left(K_{\mathrm{I} c}\right)$ of the material,

$$
K_{\mathrm{Ic}}=\cos \frac{\theta_{0}}{2}\left[K_{\mathrm{I}} \cos ^{2} \frac{\theta_{0}}{2}-\frac{3}{2} K_{\mathrm{II}} \sin \theta_{0}\right] .
$$

Table 1 presents the corresponding values of stress intensity factors for different rack depths in the carabiner loaded by $1200 \mathrm{~N}$ computed. Corresponding values of $K_{\mathrm{I}}$ and $K_{\mathrm{II}}$ computed for each crack depth can then be replaced into Eq. (9) to assess the onset of fracture. Accordingly, Table 2 shows the critical crack depth $\left(W_{c}\right)$ for which the unstable crack growth would be expected to occur based on Eq. (9). As seen from this table, $W_{c}$ varies between 7.6 to $8.2 \mathrm{~mm}$ depending on the crack inclination angle in the analyzed carabiner. It was also found that by increasing the crack depth, the value of mode II stress intensity factor $\left(K_{\mathrm{II}}\right)$ decreases drastically for all crack inclination angles and hence the failure of carabiner at the onset of unstable crack growth would be controlled mainly by dominantly mode I (tensile or opening) type mechanism.

$\mathrm{T}$ a b 1 e 1

Corresponding Values of Mode I and Mode II Stress Intensity Factors for Different Crack Depths in the Investigated Carabiner

\begin{tabular}{|c|c|c|c|c|c|c|c|c|c|c||}
\hline \multirow{2}{*}{$\begin{array}{c}\alpha, \\
\mathrm{deg}\end{array}$} & $\begin{array}{c}K, \\
\mathrm{MPa} \cdot \mathrm{m}^{0.5}\end{array}$ & \multicolumn{9}{|c|}{$W, \mathrm{~mm}$} \\
\cline { 3 - 12 } & 1.0 & 2.0 & 3.0 & 4.0 & 5.0 & 6.0 & 7.0 & 8.0 & 8.5 \\
\hline \multirow{2}{*}{0} & $K_{\mathrm{I}}$ & 2.21 & 2.90 & 2.99 & 3.23 & 4.30 & 6.73 & 11.62 & 21.26 & 30.76 \\
\cline { 2 - 12 } & $K_{\text {II }}$ & 0.34 & 0.60 & 0.046 & 0.017 & 1.01 & 0.78 & 1.09 & 2.01 & 2.24 \\
\hline \multirow{2}{*}{15} & $K_{\mathrm{I}}$ & 1.85 & 2.42 & 2.86 & 3.72 & 5.30 & 8.00 & 13.35 & 26.62 & \\
\cline { 2 - 12 } & $K_{\text {II }}$ & 0.18 & 0.07 & 0.10 & 0.24 & 0.23 & 0.43 & 0.53 & 0.29 & \\
\hline \multirow{2}{*}{30} & $K_{\mathrm{I}}$ & 2.03 & 2.59 & 3.22 & 3.86 & 5.49 & 8.05 & 12.50 & 25.76 & \\
\cline { 2 - 12 } & $K_{\text {II }}$ & 0.08 & 0.54 & 0.27 & 0.15 & 0.12 & 0.13 & 0.05 & 0.03 & \\
\hline \multirow{2}{*}{45} & $K_{\mathrm{I}}$ & 1.81 & 2.37 & 3.00 & 3.72 & 5.27 & 7.60 & 12.78 & 27.64 & \\
\cline { 2 - 12 } & $K_{\text {II }}$ & 0.30 & 0.58 & 0.51 & 0.44 & 0.35 & 0.50 & 0.74 & 1.61 & \\
\hline \hline
\end{tabular}


$\mathrm{T}$ a b 1 e 2

Permissible Defect Depth and the Number of Loading-Unloading Fatigue Cycles

Required for Fracture of the Investigated Carabiner

\begin{tabular}{|c|c|c|c|c|}
\hline$\alpha, \operatorname{deg}$ & 0 & 15 & 30 & 45 \\
\hline$W_{c}, \mathrm{~mm}$ & 8.15 & 7.64 & 7.66 & 7.62 \\
\hline$N$, cycles & 281,950 & 283,740 & 267,350 & 295,230 \\
\hline
\end{tabular}

It should be also noted that although the risk of sudden fracturing in the investigated cracked carabiner containing small cracks and subjected to static service loads is very low but repeated loads applied to these devices may facilitate the required conditions for graduall fatigue crack growth. In practice, a carabiner experiences a large number of loading and unloading cycles during its service life. Consequently, it is important and necessary to investigate the remaining life of the cracked carabiners subjected to repeated cyclic fatigue loads.

A general fatigue crack growth model for a cracked body subjected to mixed mode I/II loading can be written as [38]:

$$
d a / d N=B^{*}\left(\Delta K_{e f f}\right)^{m^{*}},
$$

where the parameters $a$ and $N$ are the crack length (or depth) and the number of cycles, respectively. The coefficients $B^{*}$ and the exponents $m^{*}$ can be found by test for mixed mode [38]. As previously mentioned, by increasing the crack depth the value of $K_{\text {II }}$ becomes negligible in comparison with $K_{\mathrm{I}}$. Therefore, the mixed mode I/II fatigue crack propagation models can be simplified to the pure mode I condition. Other papers (e.g., [39]), have also used such a simplification for fatigue life predictions of structural components in practical applications. For estimating the fatigue life of the cracked carabiner containing a growing defect under mode I loading conditions the well-known Paris-Erdogan fatigue crack growth model presented by Paris and Erdogan [40]:

$$
d a / d N=C(\Delta K)^{m}
$$

can be utilized. The parameters $C$ and $m$ could be obtained for the material by conducting standard fracture tests and from the available handbooks. The values of $C$ and $m$ for the Al-7075 material were obtained equal to $2.7 \cdot 10^{-11}$ (m/cycle) and 3.7 , respectively [41]. The cycles to failure for the investigated carabiner could be calculated as follows:

$$
\frac{d W}{d N}=C \Delta K^{m} \rightarrow N=\frac{1}{C} \int_{W_{i}=1 \mathrm{~mm}}^{W_{c}} \frac{d W}{\Delta K^{m}} .
$$

The parameters $W_{i}$ and $W_{c}$ are the initial and the critical crack depths, respectively. Accordingly, the remaining service life cycles of the investigated carabiner subjected to repeated $1200 \mathrm{~N}$ to zero loading-unloading cycles can be simply obtained from Eq. (12) by knowing the dependency of $K$ on crack depth $W$. By performing several finite element analyses, variations of stress intensity factor with crack depth were obtained by curve fitting of a polynomial to the $K-W$ data. Table 2 presents the number of required loading 
cycles computed based on Eq. (12) for growing a crack of depth $W_{i}=1 \mathrm{~mm}$ to $W_{c}$ in the investigated carabiner for different crack inclination angles.

It should be finally noted that although the Al-7075 material exhibits elastic-plastic behavior at the onset of fracture but the range of applied loads in the real and practical situations to the carabineres are very less than the ultimate strength of the material (typically about one tenth of the yield strength of Al-7075). This implies that the service loads applied to the carabiners are limited to the elastic portion of stress-strain curve and the use of linear elastic relations for obtaining the fracture parameters and also the fatigue crack growth are valid and applicable.

\section{Con c l us ions}

1. A three-dimensional carabiner containing a 3D edge crack was modeled and analyzed to obtain its fracture parameters.

2. While mode III deformation was negligible for the analyzed carabiner, the fracture behavior of the carabiner was mainly controlled by a mixed mode I/II mechanism for small cracks.

3. Values of stress intensity factors $\left(K_{\mathrm{I}}\right.$ and $\left.K_{\mathrm{II}}\right)$ and $T$-stress were computed for different crack depths, crack lengths and crack orientation relative to the loading direction.

4. Mode I stress intensity factor increases generally for longer and deeper cracks with smaller crack inclination angles. But variation of $K_{\mathrm{II}}$ depends on the geometry and loading conditions of the investigated crack. The $T$-stress had also noticeable nehative values in the analyzed carabiner.

5. Permissible defect size was determined for the investigated carabiner using the critical fracture toughness of Al-7075 alloy and a mixed mode fracture criterion.

6. Using a fatigue crack growth model, the remaining service life of the investigated cracked carabiner subjected to repeated loading-unloading cycles was estimated for different crack orientation angles.

\section{Резюме}

Виконано числове моделювання процесу втомного руйнування з'єднувального карабіна зі сплаву Al-7075 із малою крайовою тріщиною для типових умов експлуатаційного навантаження. Із використанням методу скінченних елементів у тривимірній постановці визначено характеристики руйнування матеріалу за змішаною модою для різних умов навантаження і конфігурацій тріщини (включаючи їі довжину, глибину і кут нахилу). Згідно з отриманими результатами деформацією досліджуваного карабіна по моді III через іiі малість можна знехтувати, внаслідок чого руйнування відбувається за змішаним механізмом відриву-зсуву (змішана мода I/II). Проведено розрахунок коефіцієнтів інтенсивності напружень $\left(K_{\mathrm{I}}\right.$ i $\left.K_{\text {II }}\right)$ і сингулярних $T$-напружень. Показано, що знак та значення цих параметрів руйнування визначаються геометрією та орієнтацією тріщини. Розраховано критичну довжину тріщини та живучість карабіна $з$ тріщиною при повторно-змінному навантаженні на основі відомих критеріїв руйнування і моделей росту втомної тріщини.

1. D. Secunda, Standards for Climbing, ASTM Standardization News, February 1994.

2. M. Walk, "Strain/displacement of a carabiner via interferometry," Laser Interferometry $X, 4101,409-417$ (2000). 
3. D. Custer and K. Dave, Preliminary Research Literature, ASTM/CE Standard.

4. K. B. Blair, D. Custer, J. M. Graham, et al., "Analysis of fatigue failure in D-shaped carabiners," Sports Eng., 8, 107-113 (2005).

5. V. Scott, Design of a Composite Carabiner for Rock Climbing, Final Year Project, Mechanical Engineering, Imperial College London, June 2008.

6. M. L. Williams, "On the stress distribution at the base of a stationary crack," J. Appl. Mech., 24, 109-114 (1957).

7. M. R. Ayatollahi and M. R. M. Aliha, "Wide range data for crack tip parameters in two disc-type specimens under mixed mode loading," Comput. Mater. Sci., 38, No. 4, 660-670 (2007).

8. D. J. Smith, M. R. Ayatollahi, and M. J. Pavier, "The role of T-stress in brittle fracture for linear elastic materials under mixed mode loading," Fatigue Fract. Eng. Mater. Struct., 24, 137-150 (2001).

9. M. R. M. Aliha, M. R. Ayatollahi, D. J. Smith, et al., "Geometry and size effects on fracture trajectory in a limestone rock under mixed mode loading," Eng. Fract. Mech., 77, 2200-2212 (2010).

10. T. Fett, "Stress intensity factors and T-stress for internally cracked circular disks under various boundary conditions," Eng. Fract. Mech., 68, 1119-1136 (2001).

11. A. Sutradhar and G. H. Paulino, "Symmetric Galerkin boundary element computation of T-stress and stress intensity factors for mixed-mode cracks by the interaction integral method," Eng. Anal. Bound. Elem., 28, No. 11, 1335-1350 (2004).

12. J. H. Kim and G. H. Paulino, "T-stress, mixed-mode stress intensity factors, and crack initiation angles in functionally graded materials: a unified approach using the interaction integral method," Comput. Meth. Appl. Mech. Eng., 192, 1463-1494 (2003).

13. K. Tanaka, Y. Teranishi, and S. Ujihashi, "Finite element modelling and simulations for golf impact," Proc. Inst. Mech. Eng., Part P: J. Sports Eng. Tech., 227, No. 1, 20-30 (2013).

14. S. D. Burbank and L. V. Smith, "Dynamic characterization of rigid foam used in finite element sports ball simulations," Proc. Inst. Mech. Eng., Part P: J. Sports Eng. Tech., 226, No. 2, 77-85 (2012).

15. P. Luque, D. A. Mantaras, and A. Pello, "Racing car chassis optimization using the finite element method, multi-body dynamic simulation and data acquisition," Proc. Inst. Mech. Eng., Part P: J. Sports Eng. Tech., 227, No. 1, 3-11 (2013).

16. T. Allen, S. Haake, and S. Goodwill, "Effect of friction on tennis ball impacts," Proc. Inst. Mech. Eng., Part P: J. Sports Eng. Tech., 224, No. 3, 229-236 (2010).

17. P. Drane, J. Sherwood, R. Colosimo, et al., "A study of wood baseball bat breakage," Proc. Eng., 34, 616-621 (2012).

18. J. T. M. Cheung and M. Zhang, "Finite element modeling of the human foot and footwear," in: ABAQUS User's Conference (2006), pp. 145-159.

19. ABAQUS Theory and User's Manual, Version 6.4, Hibbitt, Karlsson, and Sorensen Inc., Pawtucket, RI (2004).

20. H. A. Richard, Role of Fracture Mechanics in Modern Technology, Elsevier Science Publishing, North-Holland (1987).

21. X. Yan, Z. Zhang, and S. Du, "Mixed mode fracture criteria for the materials with different yield strengths in tension and compression," Eng. Fract. Mech., 42, 109-116 (1992). 
22. H. C. Rhee and M. M. Salama, "Mixed-mode stress intensity factor solutions of a warped surface flaw by three-dimensional finite element analysis," Eng. Fract. Mech., 28, No. 2, 203-209 (1987).

23. S. C. Forth, L. H. Favrow, W. D. Keat, and J. A. Newman, "Three-dimensional mixed-mode fatigue crack growth in a functionally graded titanium alloy," Eng. Fract. Mech., 70, No. 15, 2175-2185 (2003).

24. K. Tanaka, "Fatigue crack propagation from a crack inclined to the cyclic tensile axis," Eng. Fract. Mech., 6, 493-507 (1974).

25. Y. Liu and S. Mahadevan, "Threshold stress intensity factor and crack growth rate prediction under mixed-mode loading," Eng. Fract. Mech., 74, No. 3, 332-345 (2007).

26. M. R. Ayatollahi, M. R. M. Aliha, and H. Saghafi, "An improved semi-circular bend specimen for investigating mixed mode brittle fracture," Eng. Fract. Mech., 78, 110-123 (2011).

27. M. R. M. Aliha, M. R. Ayatollahi, and R. Pakzad, "Brittle fracture analysis using a ring shape specimen containing two angled cracks," Int. J. Fract., 153, No. 1, 63-68 (2008).

28. M. R. M. Aliha and M. R. Ayatollahi, "Geometry effects on fracture behavior of polymethyl methacrylate," Mater. Sci. Eng. A, 527, No. 3, 526-530 (2010).

29. H. Saghafi, A. Zucchelli, and G. Minak, "Evaluating fracture behavior of brittle polymeric materials using an IASCB specimen," Polym. Test., 23, 133-140 (2013).

30. M. R. M. Aliha and M. R. Ayatollahi, "On mixed-mode I/II crack growth in dental resin materials," Scripta Mater., 58, 258-261 (2008).

31. M. R. M. Aliha and M. R. Ayatollahi, "Analysis of fracture initiation angle in some cracked ceramics using the generalized maximum tangential stress criterion," Int. J. Solids Struct., 49, No. 13, 1877-1883 (2012).

32. P. S. Leevers and J. C. Radon, "Inherent stress biaxiality in various fracturespecimen geometries," Int. J. Fract., 19, 311-325 (1982).

33. F. Erdogan and G. C. Sih, "On the crack extension in plates under plane loading and transverse shear," J. Basic Eng., 85, 519-525 (1963).

34. G. C. Sih, "Strain-energy-density factor applied to mixed mode crack problems," Int. J. Fract., 10, 305-321 (1974).

35. M. A. Hussain, S. L. Pu, and J. Underwood, "Strain energy release rate for a crack under combined mode I and mode II," in: Fracture Analysis, ASTM STP 560, Philadelphia (1974), pp. 2-28.

36. F. J. Gomez, M. Elices, F. Berto, et al. "Fracture of U-notched specimens under mixed mode: experimental results and numerical predictions," Eng. Fract. Mech., 76, No. 2, 236-249 (2009).

37. http://asm.matweb.com/search/SpecificMaterial.asp?bassnum=MA7075T6.Aluminum707 5-T6; 7075-T651-ASM Material Data Sheet (accessed 20 May 2013).

38. H. Zhang and A. Fatemi, "Short fatigue crack growth behavior under mixed-mode loading," Int. J. Fract., 165, No. 1, 1-19 (2010).

39. A. R. Torabi and M. R. M. Aliha, "Determination of permissible defect size for solid axles loaded under fully-reversed rotating bending," Eng. Solid Mech., 1, 27-36 (2013). 
40. P. C. Paris and F. A. Erdogan, "Critical analysis of crack propagation laws," J. Basic Eng., 85, 528-533 (1963).

41. Damage Tolerant Design Handbook: A Compilation of Fracture and Crack Growth Data for High Strength Alloys, Vol. 1: A Compilation of Fracture and Crack Growth Data for High-Strength Alloys, Metals, and Ceramics, Information Center (U.S.) CINDAS/Purdue University, Lafeyette, IN (1994).

Received 20. 09. 2014 